Received: 20/05/2019

Revision: 07/11/2019

Accepted: 14/11/2019

OnlineFirst:13/01/2020

\title{
The Use of Critical Thinking Aspects on Module to Enhance Students' Academic Achievement
}

\section{Yoga Dwija Wicaksana}

Graduate student of Science Education, Universitas Sebelas Maret, Central Java, Indonesia,dwijayoga@gmail.com

\section{Sri Widoretno}

Corresponding author, Advisor, Faculty of Teacher Training and Education, Universitas Sebelas Maret, Central Java, Indonesia, widoretnosri@ gmail.com

\section{Sri Dwiastuti}

Co-Advisor, Faculty of Teacher Training and Education, Universitas Sebelas Maret, Central Java, Indonesia, dwiastuti54@gmail.com

This study aimed to determine the effectiveness of critical thinking aspects on the module to enhance students' academic achievement of human circulatory system. Research participants were 8th grade of junior high school students, which assigned into experimental and control groups (each group consists of 27 students) based on One-Way ANOVA result $(0.255$; p-value > 0.05). This quasiexperimental study applied a pre-test and post-test non-equivalent control group design. An analysis of covariance (ANCOVA) was used to analyse pre-test and post-test data, with pre-test as a covariate. Analysis result showed that: 1) students' academic achievement in the experimental group is significantly different with the control group ( $\mathrm{F}=90.562$; $\mathrm{p}$-value $<0.05)$; 2 ) students' academic achievement gap in the experimental group is lower than the control group; and 3) applying critical thinking aspects on the module have an effective contribution of $64 \%$ in students' academic achievement enhancement of the experimental group. Therefore, the use of critical thinking aspects on the module has a good impact on students' academic achievement.

Keywords: critical thinking, module, academic achievement, human circulatory system, junior high school students, human circulatory system

\section{INTRODUCTION}

Learning activities need to empower students' critical thinking skills because it has a positive impact on several fields such as creative thinking (Ülger, 2016), decision

Citation: Wicaksana, Y. D., Widoretno, S., \& Dwiastuti, S. (2020). The Use of Critical Thinking Aspects on Module to Enhance Students' Academic Achievement. International Journal of Instruction, 13(2), 303-314. https://doi.org/10.29333/iji.2020.13221a 
making (Kashaninia, Yusliani, Hosseini, \& Soltani, 2016), problem-solving (Kanbay \& Okanl1, 2017), and academic achievement (Alessio, Avolio, \& Charles, 2019; Pitt, Powis, Levett-Jones, \& Hunter, 2015). Critical thinking able to improve students' academic achievement because it provides a learning experience which involves highorder thinking skills according to students' cognitive development stages (Kwan \& Wong, 2015). Critical thinking also offers students a complex and deeper understanding of the concepts (Dwyer, Hogan, \& Stewart, 2014) they have learned and encourages them to analyze and evaluate various information to make a logical conclusion (Shehab \& Nussbaum, 2015). Thus, student learning activities in the classroom should focus on how to support students to think critically.

Critical thinking has a positive correlation with academic achievement, especially in the cognitive process of analyzing, evaluating, and synthesizing (Adams, 2017; Assaly \& Smadi, 2015; Safitri, Irmawanty, Bachtiar, \& Rukman, 2018). Critical thinking can promote students' cognitive processes towards higher levels of thinking (Adams, 2017; Saido, Siraj, Bakar, Nordin, \& Saadallah, 2015). In addition, students are also capable to solve various problems, including quiz questions or tests given by the teacher (Alburaidi \& Ambusaidi, 2019; Safitri et al., 2018). Critical thinking also encourages students to make questions that represent their deeper understanding of a phenomenon (Assaly \& Smadi, 2015). However, the lack of learning activities that are oriented to encourage students to think critically will affect students' academic achievement.

Students' academic achievement based on analysis of a junior high school national exam result from 2011 to 2018 showed that human circulatory system had the lowest average score compared to another topics. The human circulatory system had an average score of $41.29 \%$ followed by human digestive $(51.5 \%)$ and reproductive system $(53.31 \%)$. Average school level score of human circulatory system $(41.29 \%)$ also had a lower than regional $(53.14 \%)$, provincial $(47.18 \%)$ and national levels $(54.35 \%)$ (Kemdikbud, 2018). According to analysis data, there should be an effort to enhance students' academic achievement, which is relatively low.

Several prior researches confirm that using module that oriented towards critical thinking as learning material able to improve students' academic achievement (Christiyoda, Widoretno, \& Karyanto, 2016; Hairida, 2016; Irwan, Maridi, \& Dwiastuti, 2019; Khasanah, Sajidan, \& Widoretno, 2017; Puspitasari, Widoretno, \& Prayitno, 2015; The, Isa, \& Omar, 2018). Module that is concerned with critical thinking process affords content with specific activities that have capabilities of advancing critical thinking aspects (CTa) (Khatib \& Alizadeh, 2012; The et al., 2018; Tung \& Chang, 2009).

CTa consist of interpretation, analysis, evaluation, inference, explanation, and selfregulation (Facione, 2015). All aspects are visualized into the module as learning objectives, learning material, learning activities, and assessment (Daryanto, 2013; Khasanah et al., 2017; Prastowo, 2015; Puspitasari et al., 2015; Sukiman, 2012). The proportion of CTa on the module must be considered. In a case that the proportion is very low, students will find difficulties in improving their academic achievement (Khasanah et al., 2017; Pitt et al., 2015; Puspitasari et al., 2015) as found in a junior 
high school module of human circulatory system. Thus, concern with the proportion of $\mathrm{CTa}$ on the module is necessary. If the proportion of CTa is sufficient to develop students' critical thinking, then it will have a good impact on students' academic achievement. Students who have the ability to think critically well tend to have a better academic achievement (Alessio et al., 2019; Khasanah et al., 2017; Pitt et al., 2015; Puspitasari et al., 2015).

Based on the explanation above, it requires a study to determine whether the use of CTa on the module is effective in improving students' academic achievement. Hence, this study aims to find out: 1) whether implementing module that contain CTa compared to module commonly used in a junior high schools has a different impact on students' academic achievement; 2) whether the use of CTa on the module can reduce students' academic achievement gap; and 3) how is the effectiveness of CTa on the module in enhancing student students' academic achievement.

\section{METHOD}

\section{Research Design}

This quasi-experimental research was applied pre-test and post-test nonequivalent control group design which conducted at SMP PGRI 15 Sukolilo. Research design is illustrated in Table 1.

Table 1

Research Design

\begin{tabular}{llll}
\hline Group & Pre-test & Variable & Post-test \\
\hline Experimental & $\mathrm{Y}_{1}$ & $\mathrm{X}_{1}$ & $\mathrm{Y}_{3}$ \\
Control & $\mathrm{Y}_{2}$ & $\mathrm{X}_{2}$ & $\mathrm{Y}_{4}$ \\
\hline
\end{tabular}

Student's academic achievement data in experimental and control groups were obtained from pre-test and post-test. Pre-test generates student's academic achievement data in experimental $\left(\mathrm{Y}_{1}\right)$ and control groups $\left(\mathrm{Y}_{2}\right)$ before applying the module, while post-test provides student's academic achievement data of experimental $\left(\mathrm{Y}_{3}\right)$ and control groups $\left(\mathrm{Y}_{4}\right)$ after module was implemented. Module that contains CTa $\left(\mathrm{X}_{1}\right)$ was used by students in experimental group as a learning material, whereas module that commonly used at school $\left(\mathrm{X}_{2}\right)$ was implemented in control group.

\section{Research Sample}

Cluster random sampling technique was applied to determine research samples among population of 8th grade students $(\mathrm{N}=105)$. Research samples were decided based on analysis result of One-Way ANOVA (p-value > 0.05) after student's academic achievement data were confirmed normal and homogeneous. The test result of One-Way ANOVA was used to ensure that student's academic achievements have no significant differences. As a result, two classes can be decided as experimental and control groups randomly.

\section{Limitations}

This study has limitations relating to the module implementation and the problems discussed. Module implementation did not use specific learning models that directly 
support the critical thinking process. The teacher applies learning model in accordance with his lesson plan. Modules in this study are used as learning materials that can be applied in various learning activities based on the teacher's lesson plan. This study discusses specific learning problem that occur in 8 grade of SMP PGRI 15 Sukolilo on human circulatory system topic. Hence, this research has limitations related to efforts to overcome this problem through the use of critical thinking aspects on the module. Learning problem in this school may not be the same as other schools in general.

\section{Instrument}

The instrument that used to measure students' academic achievement consists of 25 multiple choice questions. Instruments are made based on the integration results between CTa, cognitive processes of analyzing, evaluating, and synthesizing (Anderson et al., 2001), and human circulation system (blood, organ, and disorders). The instrument was established for validity and reliability. Validity test was conducted through expert analysis. Two experts were included to test the validity of the instrument. Experts stated that the instrument was valid with validity index of 3.83 and 3.65. Reliability of instrument was tested using Kuder and Richardson 20 formula. Reliability test showed that the instrument was reliable with reliability index of 0.84 .

\section{Data Analysis}

Pre-test and post-test data was analyzed using ANCOVA (p-value $<0.05$ ). The use of ANCOVA aims to determine whether students' academic achievements between the experimental and control groups significantly different. Pre-test score was defined as a covariate to eliminate the variation of original students' academic achievement among samples. ANCOVA is carried out after the prerequisite test is fulfilled. Prerequisite test consist of parametric, interaction, and correlation test (Widhiarso, 2011). Parametric test used to measure normality and homogeneity data. Normality data tested with Kolmogorov-Smirnov (p-value $>0.05$ ) and homogeneity data measured with Levene's test (p-value $>0.05)$. Interaction test aims to ensure that groups of sample do not have interaction with student's pre test scores ( $p$-value > 0.05) and correlation test purposed to confirm that pre-test is a covariate of student's academic achievement regarding to post-test score (p-value < 0.05). Effect size of critical thinking module is defined according to partial eta squared value. The statistical calculations data were using SPSS 21 with significance level of 0.05 .

\section{FINDINGS}

Research findings presented according to five stages that carried out during the research. Specifically: 1) determination of the experimental and control groups; 2) pre-test; 3) implementation of module as learning material; 4) post-test; 5) measuring the effectiveness of using CTa on module.

\section{Determination of the Experimental and Control Groups}

Experimental and control groups were determined by using One-Way ANOVA test. The results of One-Way ANOVA test are visualized in Table 2. 
Table 2

One-Way ANOVA Test Result

\begin{tabular}{lllll}
\hline \multirow{2}{*}{ Classes } & \multirow{2}{*}{$\sum$ Students } & Tests & & \\
\cline { 3 - 5 } & 27 & Normality & Homogeneity & One-Way ANOVA \\
\hline VIII A & 27 & 0.200 & 0.817 & 0.255 \\
VIII B & 26 & 0.119 & & \\
VIII C & 25 & 0.200 & & \\
VIII D & 0.164 & & \\
\hline
\end{tabular}

The results of normality test for all classes are: 1) VIII $\mathrm{A}=0.200 ; 2$ ) VIII $\mathrm{B}=0.119 ; 3$ ) VIII $\mathrm{C}=0.200$; and 4) VIII $\mathrm{D}=0.164$. Normality test result showed that students' academic achievement data are normally distributed ( $\mathrm{p}$-value $>0.05)$. The homogeneity test results of all classes were 0.817 which means that students' academic achievement data were homogeneous ( $\mathrm{p}$-value $>0.05$ ). Results of normality and homogeneity tests indicate that students' academic achievement data were normally distributed and homogeneous.

Analysis result of One-Way ANOVA was 0.225, higher than alpha level of 0.05. This means that student's academic achievement data were not significantly different. Therefore, cluster random sampling technique can be applied. Students in class VIII A was decided randomly as experimental group and class VIII B as control group.

\section{Pre-Test}

Pre-test was carried out in experimental and control groups before the module was applied as a learning material of human circulatory system. Pre-test results are presented in Table 3.

Table 3

Pre-Test Result

\begin{tabular}{llllll}
\hline \multirow{2}{*}{ Groups } & \multirow{2}{*}{ Students } & Score & Gap & Mean \\
\cline { 2 - 4 } & & Lowest & Highest & & \\
\hline Experimental & 27 & 20.00 & 54.29 & 34.29 & 40.74 \\
Control & 27 & 25.71 & 57.14 & 31.43 & 43.91 \\
\hline
\end{tabular}

The number of students in experimental and control groups were 27. Pre-test results showed that the experimental and control groups had different value of lowest score, highest score, gap, and mean. The lowest and highest score in experimental group were 20.00 and 54.29, with gap of 34.29, whereas 25.71 and 57.14 , with ranges of 31.43 in control group. The mean value of experimental group was 40.74 and control group was 43.91.

\section{Implementation of Module as Learning Material}

Implementation of module in experimental and control groups was carried out for five meetings. The first meeting was pre-test. The second to fourth meeting were learning activity of human circulatory system which divided into three subtopics (i.e. blood, organs, and disorders). Students learned one subtopic at each meeting. The last meeting was a post-test. This is an evaluation step to measure students' academic achievements after all subtopics on the module had been studied. 


\section{Post-Test}

Post-test was performed after module with CTa and module commonly used in school were applied as student learning material in experimental and control group. Post-test results are presented in Table 4.

Table 4

Post-Test Result

\begin{tabular}{llllll}
\hline \multirow{2}{*}{ Groups } & \multirow{2}{*}{ Students } & \multicolumn{2}{l}{ Score } & Gap & Mean \\
\cline { 2 - 4 } & & Lowest & Highest & & \\
\hline Experimental & 27 & 57.14 & 80.00 & 22.86 & 67.94 \\
Control & 27 & 48.57 & 74.29 & 25.72 & 64.13 \\
\hline
\end{tabular}

Table 4 showed that the number of students participating in the post-test remains 27 students both in experimental and control groups. The lowest and highest score in experimental group were 57.14 and 80 , with gap score of 22.86 , whereas 48.57 and 74.29 , with gap score of 25.72 in control group. The mean value of experimental and control groups were 67.94 and 64.13.

\section{Measuring the Effectiveness of Using CTa on Module}

Measuring the effectiveness of CTa on module was preceded by normality and homogeneity tests. Normality and homogeneity test result of the pre-test and post-test data in the experimental and control groups are presented in Table 5.

Table 5

Normality and Homogeneity Test Results

\begin{tabular}{lllll}
\hline \multirow{2}{*}{ Data } & \multirow{2}{*}{ Groups } & $\sum$ Students & Statistical Tests & \\
\cline { 3 - 5 } & Experimental & 27 & Normality & Homogeneity \\
\hline Pre-test & Control & 27 & 0.132 & 0.076 \\
& Experimental & 27 & 0.148 & 0.455 \\
\hline Post-test & Control & 27 & 0.455 & \\
& &
\end{tabular}

Table 5 showed that: 1) normality test results of pre-test and post-test data in the experimental group were 0.132 and $0.200 ; 2$ ) normality test results of the pre-test and post-test data in the control group were 0.148 and 0.120 . The results of the normality test of the experimental group and control exposed that the pre-test and post-test data of both groups were normally distributed ( $\mathrm{p}$-value $>0.05$ ). The homogeneity test results of the pre-test and post-test data were 0.076 and 0.455 , which means that both data are homogeneous ( $\mathrm{p}$-value $>0.05$ ).

The next stage is interaction and correlation tests. Interaction test was conducted to determine whether there is interaction between group variables and pre-test scores while the correlation test was conducted to decide whether there was a correlation between the pre-test and post-test scores. The interaction and correlation test results are presented in Table 6. 
Table 6

Interaction and Correlation Test Results

\begin{tabular}{lll}
\hline Tests & $\mathrm{P}$ & Information \\
\hline Interaction & 0.259 & - \\
Correlation & $0.000^{*}$ & *pearson correlation of 0.814 \\
\hline
\end{tabular}

The interaction test result between groups and pre-test was 0.259 ( $\mathrm{p}$-value $>0.05$ ), which means there is no interaction between the group variables and the pre-test data. The correlation test result between pre-test and post-test data was 0.000 with pearson correlation 0.814 ( $\mathrm{p}$-value $<0.05$ ), which means there is no interaction between the group variables and the pre-test data.

There is a correlation between the pre-test data and the post-test with the pearson correlation value of 0.814 . Pearson correlation value indicates that the pre-test strongly correlates with the post-test. Hence, it can be concluded that pre-test is a covariate of students' academic achievement that represented by post-test score. Interaction and correlation test result of pre-test and post-test data stated that they were eligible for ANCOVA test as presented in Table 7.

Table 7

ANCOVA Test Result (Dependent Variable: Post-Test)

\begin{tabular}{llll}
\hline Source & F & P & Partial Eta Squared \\
\hline Group & 90.562 & 0.000 & 0.640 \\
\hline
\end{tabular}

ANCOVA test results showed that students' academic achievement of experimental and control groups are significantly different $(\mathrm{F}=90.562$; p-value $<0.05)$. The implementation of module which contains CTa made an effective contribution of 0.64 or $64 \%$ in improving students' academic achievement of experimental group, according to partial eta squared value. The comparison of students' academic achievement average score in experimental and control groups is presented in Table 8.

Table 8

Comparison of Students' Academic Achievement Average Score

\begin{tabular}{llll}
\hline Groups & Pre-test & Post-test & Enhancement \\
\hline Experimental & 40.74 & 67.94 & 28.14 \\
Control & 43.91 & 64.13 & 19.27 \\
\hline
\end{tabular}

Table 8 shows the differences of pre-test and post-test average score between students in experimental and control groups. The average pre-test score of students in control group was 43.91, higher than the average score of students in experimental group (40.74). But, the average post-test score of students displayed opposite results where students in experimental group had higher average scores than control group, explicitly 67.94 and 64.13. Furthermore, the average enhancement score of experimental groups (28.14) was also higher than control group (19.27).

\section{DISCUSSION}

CTa develops a series of mental abilities towards cognitive process (Facione, 2015) which related to academic achievement test in the context of cognitive processes (Anderson et al., 2001). There are cognitive processes in CTa that also include in 
academic achievement, explicitly analysing and evaluating. Therefore, encourage students to think critically on the aspects of analysing and evaluating will directly impacts on their academic achievement in terms of the ability to analyse and evaluate (Fuad, Zubaidah, Mahanal, \& Suarsini, 2017; Shehab \& Nussbaum, 2015). Even though not all cognitive processes of CTa also exist on academic achievement, but it does not mean that the remaining aspects have no impact to enhance students' academic achievement.

Facione (2015) states that interpretation is an activity to understand and express the importance of information obtained from various sources through categorization, decoding significance, and clarifying meaning. Meanwhile, according to Martin (2012) interpretation is to process of explaining specific information obtained from experimental data. So according to Facione (2015) and Martin (2012), interpretation is a process to discover important findings from experiments or data through categorization, decoding significance, and clarifying meaning.

Experimental group used module that contain interpretation activities, of course interpretation sub-skills as well (categorization, decoding significance, and clarifying meaning). Nevertheless, students' academic achievement in the experimental group is higher than students in the control group. This happens because experimental group module contains interpretation activities in different proportion. Module in the experimental group had a greater proportion of interpretation than module commonly used in school which implemented in the control group.

The level of interpretation proportion indicates the amount of activities that support students to optimize their interpretation abilities (Gelder, 2005). Engaging students in interpreting data from laboratory investigations makes learning activity become more contextual (Sari, Sudargo, \& Priyandoko, 2018). Although many interpretation activities had to be done, students in the experimental group did not look bore even more active in discussion activities than the control group according to observation result.

Interpretations can represent students' academic abilities, whereas students who are fluent in interpreting also have a good understanding of the concepts learned (Chick \& Watson, 2001; Ricketts \& Rudd, 2004). Interpretation is an integrated science process skill that facilitates students to infer the data and comprehend causal relationships between variables (Aktamiş \& Yenice, 2010; Martin, 2012). Implementing activities that are oriented to science process skills is the right option to stimulate students comprehend the concepts (Kigo, Okere, Maghanga, \& Chemwei, 2018). Comprehension requires information processing that involves a working memory. Here, memory plays an important role towards one's comprehension because it is not possible to understand correctly without any information that is remembered and which is being thought (Anderson et al., 2001). Memory works for encoding information. In addition, it builds perceptions and clarifies the significance of information that leads to the next stage of CTa, which is analysis, evaluation, and inference (Dwyer et al., 2014).

Analysis and evaluation which is CTa is also part of the academic achievements measured in this study. Consequently, learning activities that encourage students to analyse and evaluate directly have an impact on students' academic achievement as 
found in the research findings which also similar with Puspitasari et al., (2015) and Khasanah et al., (2017). Analysis and evaluation are able to accommodate students to engage actively in learning activities to construct the concepts (Fuad et al., 2017; Prawita, Prayitno, \& Sugiyarto, 2018). Students acquire the concepts from several facts that found over scientific activities which can be such as observation, experiments, demonstrations, and other relevant activities (Bailin, 2002; Hairida, 2016). Data collected from scientific activities improve students' curiosity about the phenomena of science and encourage students to hold discussions (Cheong \& Cheung, 2008; Kigo et al., 2018).

In this context, discussion activity involved all of CTa. The topics discussed are data from laboratory investigation as part of the instructions contained in the module (Cheung et al., 2018). Based on the observation results, after students carry out laboratory investigations, they exchange ideas to interpret and infer the data correctly and accurately. Starting from interpretation to inference process, there are involving other CTAs such as analysis and evaluation (Dwyer et al., 2014). Then, students explain the inference results to other groups and start class discussions after they are convinced that the results are precise and accurate.

Self-regulation is an independent aspect that is not included in sequence process of critical thinking (Dwyer et al., 2014). Self-regulation serves to regulate students' thinking when they are hesitant to act, find problems, persuade themselves whether the evidence they get is strong enough to convince other friends during the discussion (Zimmerman, 2002; Zumbrunn, Tadlock, \& Roberts, 2011). Observation results indicate that students express their opinions according to their perspectives during the discussion. Students express their thoughts in a very diverse way. In general, there are students who dominate discussion activities and there are students who tend to be more passive (although they also express their opinions). Students who dominate discussion activities tend to have a better understanding than those who are more passive. However, it does not mean that students who are more passive have no understanding of the content discussed at all. There are many factors that influence the level of student liveliness and that is beyond the context of this discussion.

\section{CONCLUSION}

The conclusion of this study is that the use of CTa in the module has a good impact on students' academic achievement, because module provides activities that concerned with critical thinking process. CTa has an effect on improving students' academic achievement, but interpretation is different from the other CTa. Interpretation involves other thinking processes such as analysis, evaluation, and inference, which at the end students make a conclusion to be explained to others. Including of CTa in learning activities will emphases students' learning environment that empowers students to think critically. Although it cannot be denied that the learning model also influences students' learning environment, therefore this study has limitations. The learning model is another variable that is not included in this study. The teacher did not apply a specific learning model, but runs learning instructions in the module. Further research is needed to 
determine whether the application of different learning models and modules has a different impact on students' academic achievement.

\section{REFERENCES}

Adams, N. E. (2017). Bloom's taxonomy of cognitive learning objectives. J. of the Med. Library Association, 103, 152-153. https://doi.org/10.3163/1536-5050.103.3.010.

Aktamiş, H., \& Yenice, N. (2010). Determination of the science process skills and critical thinking skill levels. Procedia - Social and Behavioral Sciences, 2(2), 32823288. https://doi.org/10.1016/j.sbspro.2010.03.502.

Alburaidi, A., \& Ambusaidi, A. (2019). The Impact of using activities based on the montessori approach in science in the academic achievement of fourth grade students. Int. Journal of Instruction, 12(2), 695-708. https://doi.org/10.29333/iji.2019.12244a.

Alessio, F. A. D., Avolio, B. E., \& Charles, V. (2019). Studying the impact of critical thinking on the academic performance of executive MBA students. Thinking Skills and Creativity, 31, 275-283. https://doi.org/10.1016/j.tsc.2019.02.002.

Anderson, L. W., Krathwohl, D. R., Airasian, P. W., Cruikshank, K. A., Mayer, R. E., Pintrich, P. L., ... Wittrock, M. C. (2001). A Taxonomy of learning, teaching and assessing. New York: Addison Wesley Longman.

Assaly, I. R., \& Smadi, O. M. (2015). Using bloom's taxonomy to evaluate the cognitive levels of master class textbook's questions. English Language Teaching, 8(5), 100-110. https://doi.org/10.5539/elt.v8n5p100.

Bailin, S. (2002). Critical thinking and science education. Science \& Education, 11(4), 361-375.

Cheong, C. M., \& Cheung, W. S. (2008). Online discussion and critical thinking skills: A case study in Singapore secondary school. Aus. J. of Edu. Tec., 24(5), 556-573.

Cheung, J. J. H., Kulasegaram, K. M., Woods, N. N., Moulton, C., Anne, Ringsted, C. V., \& Brydges, R. (2018). Knowing how and knowing why: Testing the effect of instruction designed for cognitive integration on procedural skills transfer. Advances in Health Sciences Education, 23(1), 61-74. https://doi.org/10.1007/s10459-017-9774-1.

Chick, H., \& Watson, J. (2001). Data representation and interpretatoin by primary school students working in group. Mathematics Education Research J., 13(2), 91-111.

Christiyoda, S., Widoretno, S., \& Karyanto, P. (2016). Pengembangan modul berbasis kemampuan pemecahan masalah pada materi sistem ekskresi untuk meningkatkan berpikir kritis. Jurnal Inkuiri, 5(1), 74-84.

Daryanto. (2013). Menyusun Modul (Bahan Ajar untuk Persiapan Guru dalam Mengajar). Yogyakarta: Gava Media.

Dwyer, C. P., Hogan, M. J., \& Stewart, I. (2014). An integrated critical thinking framework for the 21st century. Thinking Skills and Creativity, 12, 43-52. https://doi.org/10.1016/j.tsc.2013.12.004.

Facione, P. A. (2015). Critical thinking: What it is and why it counts. In Insight 
Assessment.

Retrieved

from

https://www.researchgate.net/publication/251303244\%0ACritical

Fuad, N. M., Zubaidah, S., Mahanal, S., \& Suarsini, E. (2017). Improving junior high schools' critical thinking skills based on test three different models of learning. Int. Journal of Instruction, 10(01), 101-116. https://doi.org/10.12973/iji.2017.1017a.

Gelder, T. Van. (2005). Teaching critical thinking: Some lessons from cognitive science. Col. Teach., 53(1), 41-48. https://doi.org/10.1080/87567555.2001.10844600.

Hairida. (2016). The effectiveness using inquiry based natural science module with authentic assessment to improve the critical thinking and inquiry skills of junior high school students. Jurnal Pendidikan IPA Indonesia, 5(2), 209-215. https://doi.org/10.15294/jpii.v5i2.7681.

Irwan, I., Maridi, M., \& Dwiastuti, S. (2019). Developing guided inquiry-based ecosystem module to improve students' critical thinking skills. Jurnal Pendidikan Biologi Indonesia, 5(1), 51-60. https://doi.org/10.22219/jpbi.v5i1.7287.

Kanbay, Y., \& Okanll, A. (2017). The effect of critical thinking education on nursing students' problem-solving skills†. Contemporary Nurse, 53(3), 313-321. https://doi.org/10.1080/10376178.2017.1339567.

Kashaninia, Z., Yusliani, F., Hosseini, M., \& Soltani, P. (2016). The effect of teaching critical thinking skills on the decision making style of nursing managers. J. of ClientCentered Nursing Care, 1(4), 197-204. https://doi.org/10.15412/j.jccnc.04010405.

Kemdikbud. (2018). Laporan hasil ujian nasional. Retrieved from https://hasilun.puspendik.kemdikbud.go.id/.

Khasanah, A. N., Sajidan, \& Widoretno, S. (2017). Effectiveness of critical thinking indicator-based module in empowering studrnt's learning outcomes. Jurnal Pendidikan IPA Indonesia, 6(1), 187-195. https://doi.org/10.15294/jpii.v6i1.8490.

Khatib, M., \& Alizadeh, I. (2012). Critical thinking skills through literary and nonliterary texts in English classes. International Journal of Linguistics, 4(4), 563-580. https://doi.org/10.5296/ijl.v4i4.2928.

Kigo, J. K., Okere, M. I. O., Maghanga, C. M., \& Chemwei, B. (2018). Science process skills advance organizer and students motivation orientation in secondary school physics. Kabarak Journal of Research \& Innovation, 6(1), 79-88.

Kwan, Y. W., \& Wong, A. F. L. (2015). Effects of the constructivist learning environment on students' critical thinking ability: Cognitive and motivational variables as mediators. Int. J. of Edu. Res., 70, 68-79. https://doi.org/10.1016/j.ijer.2015.02.006.

Martin, D. J. (2012). Elementary science methods: Constructivist approach. USA: Cengage Learning.

Pitt, V., Powis, D., Levett-Jones, T., \& Hunter, S. (2015). The influence of critical thinking skills on performance and progression in a pre-registration nursing program. Nurse Education Today, 35(1), 125-131. https://doi.org/10.1016/j.nedt.2014.08.006.

Prastowo, A. (2015). Panduan Kreatif membuat Bahan Ajar Inovatif (VIII). 
Yogyakarta: DIVA Press.

Prawita, W., Prayitno, B. A., \& Sugiyarto, S. (2018). Effectiveness of a generative learning-based biology module to improve the analytical thinking skills of the students with high and low reading motivation. International Journal of Instruction, 12(1), 1459-1476. https://doi.org/10.29333/iji.2019.12193a.

Puspitasari, R. D., Widoretno, S., \& Prayitno, B. A. (2015). Pengembangan Modul Berbasis Keterampilan Berpikir Kritis untuk Memberdayakan Hasil Belajar Siswa Kelas X pada Materi Sistem Gerak Manusia (Universitas Sebelas Maret). Retrieved from https://digilib.uns.ac.id/.

Ricketts, J. C., \& Rudd, R. (2004). Critical thinking skills of FFA leaders. Journal of Southern Agricultural Education Research, 54(1), 7-20.

Safitri, D., Irmawanty, Bachtiar, S., \& Rukman, W. Y. (2018). Students' cognitive achievement, critical thinking skills, and metacognitive awareness in problem based learning. Euro. J. of Edu. Stu., 5(4), 248-258. https://doi.org/10.5281/zenodo.1318320.

Saido, G. M., Siraj, S., Bakar, A., Nordin, B., \& Saadallah, O. (2015). Higher Order thinking skills among secondary school students in science learning. The Malaysian Online Journal of Educational Science, 3(3), 13-20.

Sari, P. M., Sudargo, F., \& Priyandoko, D. (2018). Correlation among science process skill, concept comprehension, and scientific attitude on regulation system materials. Journal of Physics: Conference Series, 948(1). https://doi.org/10.1088/17426596/948/1/012008

Shehab, H. M., \& Nussbaum, E. M. (2015). Cognitive load of critical thinking strategies. Learn. and Ins, 35, 51-61. https://doi.org/10.1016/j.learninstruc.2014.09.004.

Sukiman. (2012). Pengembangan Media Pembelajaran. Yogyakarta: Pedagogia.

The, N. C., Isa, N. H., \& Omar, A. (2018). Promoting higher order thinking skills in literature class via critical thinking module (CTM). ASIAN TEFL, 3(1), 69-80.

Tung, C., \& Chang, S. (2009). Developing critical thinking through literature reading. Journal of Humanities and Social Sciences, (19), 287-317.

Ülger, K. (2016). The Relationship between creative thinking and critical thinking skills of students. Hace U. J. of Edu., 3l(4), 1-1. https://doi.org/10.16986/HUJE.2016018493.

Widhiarso, W. (2011). Aplikasi Analisis Kovarian dalam Penelitian Eksperimen Aplikasi Anakova dalam Eksperimen. Retrieved from http://widhiarso.staff.ugm.ac.id/files/Analisis Kovarian Untuk Eksperimen.pdf.

Zimmerman, B. J. (2002). Becoming A self-regulated leraning in the classroom: An overview. Theory into Practice, 41(2), 64-70.

Zumbrunn, S., Tadlock, J., \& Roberts, E. D. (2011). Encouraging self-regulated learning in the classroom: A review of literature. Virginia: Virginia Commonwealth $\mathrm{U}$. 